\title{
Patachitra of Krishna Lila: Myth, Art and Culture
}

\author{
Dr. Gopal Chandra Bayen \\ Assistant Professor in Bengali Language \& Literature \\ Pingla Thana Mahavidyalaya (Vidyasagar University), P.O.-MALIGRAM \\ Dist.-Paschim Medinipur, West Bengal. India, Pin-721140
}

\begin{abstract}
In this paper we have tried to discuss about the myth and variety of Patachitra of Krishna Lila and its artistic and cultural significance. We all know that traditional folk-art Patachitra is one of the important folk painting of India like Ricepaste Paintaing or Limestone Paintaing. According to the history of Indian folk painting, Patachitra of Krishna Lila has known as one of the favorite Pata-painting among the Indian people. According to its origin Patachitra of Krishna Lila has considered as Mythological Patachitra like Ram Lila, King Harishchandra, Chandi Mangal, Durgaleela, Sabitri satyaban etc. This type of Patachitra have seen in Puri, Murshidabad, Purulia, Purba Medinipur and Paschim Medinipur. From this type of Patachitra we can understand the actual form and transformation of Krishna Culture in general Bengali people.
\end{abstract}

Key Words: Krishna, Culture, Myth, Krishna Lila, Art, Patachitra, Folklore

\section{Introduction:}

Generally the term 'Patachitra' means hand made painting on cloths. It is related with folk-art and artistic thinking of folk people.Truly it is a good kind of folk-art. In general sense folk-art has considered as a branch of folklore. We know that the term 'art' simply means a creative expression or creation of artist. It has communicated and attracted all general people in all ages and all times. And folk-art is definitely a branch of art, which has verbally transmitted and developed in folk-groups and in folk societies. In this occasion we have to remember that the definition of 'folk art' has not been describing within two or three sentences. Because it is very dynamic art form and having variety. Beside this, it has also transmitted year after year through the whole period of civilization. In general, it may be considered as such art form which has created by folk artists. According to Encyclopedia Britannica the term 'Folk- Art' means 'Predominantly functional or utilitarian visual art created by hand (or with limited mechanical facilities) for use by the maker or a small circumscribed group and containing an element of retention - the prolonged survival of tradition. Folk art is the creative expression of the human struggle toward civilization within a particular environment through the production of useful but aesthetic buildings and objects'. Basically it has divided into two categories. One is visual and the other is nonvisual. In the broadest sense folk art also refers to the art of folk dance, folk song, folk literature, folk design, folk myth, etc Folk-art, generally formed by the non-educated or low-educated village people. It is true that they are very poor in economic condition and they have not any modern technological concept of art. But the general concept of art has existed in their blood. Particularly in the case of Patachitra we may be observed that this type of folk-art is ethnic in nature and in form it is very colorful, and also it bears myth and traditional cultural of country's rich heritage.

\section{Art of Patachitra:}

Pata- painting or Patachitra is an ancient folk-paintaing of India, which has a long history of 2500 years to its development and contribution to our society.There are many types of Patachitra has been creating, such as - Scorll Painting or Jarano Pata, Chouko Pata, Jama Pata, Saheb Pata, Kalighat pata etc. Now this kind of folkart has became a popular folk-art among Bengali people as well as Indians and also to the foreigner.

The Patuas or scroll painters were generally known as folk-artists. But they have also a credibility as composer of simple songs, which is relating to ancient and modern sociological facts. By this simple song they told a story to the viewer or audience, which belongs historical facts or human culture or mythological gods or goddesses like Rama, Krishna, Siva, Durga, Lakshmi, Sarasswati. In historical Pata they generally used famous historical facts of our civilization, like Second World War, French Revolution, War of Palashi, Life of Chaitanya, Freedom of our Country (India) etc. Beside this they mostly choosed their themes of Patachitra from the subject of Mediaeval Bengali Literature, such as Vaisnava Padavali, Chandi Mangal, Manasa Mangal, Dharma Mangal etc. We are all known that these literature are very popular among the general people of Bengal. On the other hand we may observed that Patuas are very sensitive towards modern trends of civilization or social problems of our society, such as environment pollution, misuse of drinking water, women harassment, political corruption, disease of AIDS etc. They also collect their themes of paintings from these type of social scenario. And in general context of view Patachitra may be devided into seven classes. Such as General, 
Political, Historical, Religious, Mythological, social and environmental. Now here is some example, classification and description on various Pata, as follows-

General Patachitra: All type of single image of man or woman or any kind of general art figure has considered as general Patachitra. This type of patachitra has known by another name of Chouko Patachitra or card shaped patachitra. Example-Single image of the God or Goddess, An image of animal, bird, tree etc.

Political Patachitra: This type of patachitra has formed by the characteristic of political subjects. Various political movement and also the matter of corruption has to be considered as the subject of Political Patachitra. It has not

Social Patachitra : This type of patachitra has formed by the characteristic of living organisms as applied to populations of humans and other animals. It always refers to the subject of current importance and collective coexistence. Example - Palse Polio Avijan, eradiction of Malaria, Communal harmony, Terrible Sunami, explosion in Mumbai, Tree Plantation, AIDS Awareness, Awareness on Human Rights, persecution of woman, earthquake, protest to intoxication etc.

Mythological Patachitra: This type of patachitra has formed by the characteristic of various traditional story, especially one concerning the early history of a people or explaining a natural or social phenomenon, and typically involving supernatural beings or events, which has called as myths or mythology (collected myths of a group of people). Example - Raban Badha, Sita Haran, King Harishchandra, Krishnaleela, Durgaleela, SabitreeSatyaban, Manasa Mangal, Chandee Mangal, Dharma Mangal, Annada Mangal etc.

Historical Patachitra : This type of patachitra has formed by the characteristic of history or past events. Example -Second World War, Ajaad Hind Fouj and Netaji Subhas Basu, Atom bomb in Hirosima and Nagasaki, Destruction of Babri Masjid, Terrorist attack on the World Trade Centre (U.S.A.), Saheb Pata, Life of Vidyasagar, Life of Rabindranath Thakur, Life of Vivekananda etc.

Religious Patachitra: This type of patachitra has formed by the characteristic Example - Gaji Pata, Satyapirer Pata, Jama Pata, Shakti Pata, Vaishnab Pata, Chaitanyaleela etc.

According to shape and size there are two types of Patachitra has found. These are Squre Pata or Chouko Pata and Rolling Pata or Jarhano Pata. Squre Pata or Chouko Pata is a card shaped Patachitra, which has shaped on the basis of single impression, which has no rolling portion. This type of Pata have been making from post card size to various big sizes. Post card sized Patachitras are available at the cost of Rs.10. And other type of Chouko Patas price rate has depended on the basis of it's size and quality. And the other type of Patachitra, named Jorhano Pata or Rolling Patachitra has known in various name, such as Dighal Pata, Latai Pata etc. This type of Patachitra has shaped by the hard work and devotion of Patua Artists. Generally one month to ten month has required for one Rolling Patachitra, which is depended on how the Patachitra is long. In length one rolling Patachitra may be formed within 10 feet to 40 feet. There are many panel existed in this Patachitra. This type of Patachitra based on dramatic story, which had described by the Patua Artist by the use of pater Gaan(Song of Patachitra). Patachitra of Krishna Lila has formed in both shaped. Chouko Pata or Squre Pata has shaped on a single impression of Lord Krishna. And the Jarano Patachitra has shaped on the story and life of the God Shree Krishna. Lord Krishna is one of the most popular avatars of Lord Vishnu. Krishna has worshiped in many temples around the world. These temples are famous because they are either associated with the birth of Lord Krishna or known for the architecture and history. Even the aura of spirituality has made the temples of Lord Krishna a peaceful pilgrimage for the devotees. This type of pata-painting has considered as Mythological Patachitra.

\section{Other Mythological Patachitra:}

Raban Badha - This patachitra has formed on the story of Ramayana. Central character of this Patachitra is Rabana. He was born to the sage Vishrava and his wife, the Kaikeshi. Rabana has wonder power of ten heads. He was the king of lanka. Lanka King Ravana has also various bad behavior. He kidnapped the wife of Rama(Sita). At length Ayodhya King Ram killed Ravana and saved her wife Sita. After that, Rama installed Vibhishana(Brother of Rabana) as the king of Lanka. In our sociological point of view, Ravana bears a bad image till now. He had kidnaped Sita and raped Rambha, Bedabati and many other women.To remember these bad practices general people of India seriously neglect the Ravana in Dashera festival. Because Ravana is a king of dark. Our great writer Rabindranath Tagore described Ravana as a symbol of croud, greed and disorder. A patua artist allways remenbered this thinking.

Sita Haran - This patachitra has formed on the story of the Ramayana. According to the Ramayana, the king Janaka found Sita while ploughing a place of Yagna and then adopted her as daughter. When Sita reached adulthood, king Janaka organised a 'swayambara' for the purpose of her marriage. Ayadhya prince Ramchandra has won this swayambara and gets married with Sita. One day Lanka King Ravana kidnapped Sita from forest. Ravana took her back to his kingdom in Lanka, and Sita was held as a prisoner in his palace of Ashok kanan. During her captivity, Ravana expressed his bad desire, but Sita refused. Through all the life Sita maintained her 
purity.. Sita was the avatar of Goddess Lakshmi, the consort of Vishnu. Sita is portrayed as the epitome of female purity and virtue. She follows her husband into exile and was abducted by Ravana. She was imprisoned on the island of Lanka until Rama rescued her by defeating the demon king Ravana.. Whole life she has suffered from sorrow. Kusha and Lava were the sons of Sita

King Harishchandra - This patachitra has formed on the story of the famous king Harishchandra. He had donated his entire kingdom to the sage Viswamitra for his Philosophy of Truth. His life and attitude is the noble example of Indian Philosophy and culture. The king, his wife and their loving son had engaged in hardwork for the purpose to the save of truth. The king helped the guard cremate the dead bodies, and his wife and son were used as household helpers at the Brahmin's house. One day the son had walked to the garden to pluck flowers and bitten by a snake. Then he died . His mother carried his body to Harishchandra at cremation grounds. But the king Harishchandra has not recognised his wife and son. He asked to sell her golden mangalasutra and pay the tax. By this time his wife recognized her husband. Harishchandra then came to her and recognised her as his wife and felt in deep sorrow. Then she offered half of her dress as the tax, Duty bound Harishchandra accepted and performed the last rites of their son Rohitashwa .

Durgaleela - This patachitra has formed on the story of the Goddess Durga. The Goddess Durga has considered as the supreme goddess in Shaktism. Her popularity is similar to Lord Krishna. According to Skanda Purana the goddess Parvati accounted the name "Durga". She had killed the demon Durgamaasura. Goddess Parvati is considered to be the complete incarnation of Adishakti or Goddess Durga. Her father is Himalaya and mother is Menoka. In another name the Goddess Durga has called as Mahadevi, Chandi, Kali etc. She killed various demons like Chanda, Munda, Mahisashura etc.

Sabitree-Satyaban -- This patachitra has formed on the story of Sabitree and her husband Satyaban. The story of Savitri and Satyavan has found originally in the Mahabharata. Sabitree has considered as a roll model to all Indian women for her genuine purity like Sita. She was born to the king of Madra, Aswapati. When she reached adulthood, she gets married with Satyabana. But Satyabana died within one calendar year. It was mentioned by the destiny. The God of Death, Yama had arrived there and claimed the soul of Satyavana. Savitri followed Yama as he carried the soul away. In this way Yama had impressed by Savitree's dedication and purity. Last of all Yama had granted the life to Satyavana and blessed Savitri.

Life of Shree Krishna: According to Hindu mythology the God Shree Krishna has considered as an Avatara or incarnation of Lord Vishnu. Various Hindu Purana had considered Sri Krishna's devine life to mark the passing age of Dwapara Yuga. Once upon a time in this age mother Basundhara or the Earth, unable to beared the burden of sins, which was mostly committed and regulated by the evil king Kansha. Then all the Gods of heaven appealed to the God Brahma for help. Then the God Brahma prayed to the Supreme Lord Shree Vishnu. The God Vishnu assured him that he would soon be born on earth to destroy sins. From hundred of books and also from Indian folk beliefs we came to known that the God Krishna was born in Kansha's prison. His parents were Basudeva and Devaki . Krishna was the eighth child of them. From very beginning of his childhood his life was in danger because his maternal uncle, the tyrant king Kansha was seeking to kill him. The king Kansha hared from a foretold that he would be killed by Devaki's eighth child. After his birth Shree Krishna was sent by has father Vasudeva to his foster parents Nanda and Yasoda. They lived in Gokula. He then killed various demons including Kansha. At his early life, Sri Krishna became more famous for his Brindavan lila also. He also often depicted playing the flute for his beloved Gopis including Radha - whom were female devotees. This episode of his life was very important for the development of Hindu devotional tradition. To remember this Brindaban Lila we have been playing Rasa Lila every year. Rasa Lila is concentrated on the love of Lord Krishna for Radha. This Lila played during Raspurnima, in the Bengali month of Kartik or Aghrahayana and it is found in all the states of India. Rasa Lila is very famous in Manipur, Maharastra, Uttar Pradesh, Gujarat and even some parts of Kerala. In Bengal it has also celebrated by all devotee people. Beside this Shree Krishna has considered as the real hero of the Epic Mahabharata. He gave the immortal dialogue of the Bhagabata Geeta. This episode has included in the Epic Mahabharata. The Bhagabata Geeta worldly known as Krishna's yoga and Philosophy. And the role of Arjuna described in this episode as aspiring seeker, who has been seeking to the God almighty, to known the actual truth and scope of life.The God Krishna has a deep knowledge of Society and human development. He had tried to mediate to avoid Kurukskhetra war of Mahabharata.

Various important Artistic works of Krishna Lila has had a profound impact on art and culture in India. There are many Hindu temples of the God Shree Krishna has found here and there through all over India. Such as ISKCON temple(Delhi, Vrindavan, Bangalore, Kolkata, Assam etc.), Dwarkadish temple ( Dwarka) Vrindavan Temple, Banke Bihari Temple, Krishna Balaram Mandir, Govindaji Temple, Madana Mohana Temple, Jugal Kishore Temple, Jagannath Temple, Guruvayur Temple(Kerala) etc. It has also inspired that many literary works has formed in various Indian languages. Such as Bhagabata puran, Mahabharata, Vaisnava Padabalee etc. Beside this Patua artist has been formimg various patachitra of Krishna Lila from thousand of years. Here is some example of Patachitra Song of Krishna Lila have collected by me from Gurupada Chitrakar, Chittaranjan Maiti, Khandu Chtrakar. This songs of patachitra had originally formed in Bengali language. I had tried to translated these in Roman Alphabet and English pronunciation. 
KRISHNA LILA

Jale krishna sthale krishna krishna Mahimandale

Eka krishna nam dhare jagatsansare.

Kaliya kadamba mule nagariya thana

Baner banaful dekhun thakurer gale.

Kachbera kanchanbera aro bera dhara

Radhakrishna Radhakrishna vinna nai aki range jhora.

Khol baje karatal baje mridanga baje hate

Bakumurari baje sakhiganer mukhe

Chari dhare sakhigan madhye shyamrai

Dhale Dhale paren dekhun ramanider gai.

Khelarase chilen kanai gopider sane

Heriye gopikar bastra pare gelo mone.

Pahare bastra thuye sakhigan sinane namilo

Snan ahnik kare sakhira pahar pane chailo

Jhar nai jhankar nai gopir bastra keba hare

Nander beta chikan kala gopir bastra dalete bendheche.

Bastra dao thakur poridhan kori

Sukno bastra peye nam rakhib kali.

Kali kali bolis na go suno goyalar jhi

Bidhata korechen kalo amar sadhya ki?

Bastra jadi na dio thakur jabo kansa rajar thai

Kangseri tape kanaier jati kul nai.

Bare bare dis na tora kangser tulana

Abodh kale badhechilam bhagini Putana

Gach hote nam o thakur pere dao phul

Dal bhenge pare marbe sunya hoye Gokul

Dal beri bastra pere dilo

Douradouri goyalar kannya grihe chale gelo.

Saj saj bale barhai nagare dile sarha

Barhai barta paye sajlo goyal para

Guchao he kesh petari subarnar chiruni

Subarnar chirunite kesh gulike karle gota gota

Tar madhye tule nilen chandaner phonta.

Sakhira bale amra je mathura jabo bhar ke bandhibe

Jagadiswar Har achen tini bhar hohaben

Sub subarnar bank dilen belulla pater sike

Krishner kandhe diye bhar chalilo

Thakur bale ami to boyai nai bhar jagateri sar

Sriradhikar premer jannyo skandhe boi bhar.

Barai bale kheyechen radher majuri kanai hoyechen biragi

Ekhan keno balo kanai bhar boite nari.

Jetha dadhi dugdha na bikabe kanai

Setha loye jabo moneri kheyale Shyam he tomake nagare firabo.

Amra bechibo doi dugdha tumi sadhba karhi

Ekti karha kom hole marbo chongar bari.

Lajjate lajjita hoye kanai boslen daner ghate.

Sab sakhike par karite aj libo ana ana

Sriradhake par karite liba karner sona.

Sona lao sari lao thakur sakal dite pari

Dukul Jamuna Ganga hente jete nari.

Tinkhan kastha diye tabe nouka nirman karilo.

Noukar gumane braja gopini karen par.

Darai goyalar kanya buke maren gha

Kaj nai kanaiya tomar bhanga la.

Bhanga loy chura loy amar majuria kanrhi

Hasti ghora par karechi radhe katai bhari

Kather dese thako Kanai kather kiba dukh

Bhanga laya kheya dite katoi pachen sukh.

Eparer nouka Kanai opare nagailo

Douradouri goyaler kanya mathura chalilo.

Bhagyabati ma jasoda nabani chatai

Dada Balaram bachur dhare rai.

Kalo Krishna Dhabalmukhi gai doyai maner sukhe

Chongate na ante dugdha dhalen chandramukhe.

Chura dilo dhara dal panchuni dilen hate

Godhan charate jaben dada balaramer sathe

Ramer hate Shyamake diye balen Nandarani

Amar gopal gosthe jabe ane debe tumi.

Khabar samay khete dio khir sar naban

Tarur chayate rekho Gopal gunamoni.

Saj Saj ba'le rakhalgan gosthate sajila

Talban tamalban madhuban nikunjaban

Thakur sakali nirman karilo. 
Madhubane madhu kheye dada Balaram dhaliya parilo.

Seikhane chilen giri Gobardhan

Mar mar bale Giridhar parite lagilo.

Dwadas rakhal gan kache angule thek diye parbat dharan karilo

Sei din hote thakurer Giridhar nam rakhilo

Kalidaher kule chilo keli kadamber gach

Tate charhe Krishnachandra diyechilen jhap.

Kalinag aj ahar bole sakale gherilo

Nagbati duiti kanya upasthit hoilo.

Nager mathai pad diye dekhun thakur nachite lagilo

Nag bale dekhun amar jashobhagya holo

Krishner padapadma bujhi mastake uthilo.

Joy diye bandilam ma joy Bisahari

Astanage bhar karen padmer kumari

Padma phule janmo ma padma nam Kamala

Khaira kharasi ma tor hridayer kanchuli

Ajagarh borate basilen bisahari

Unkoti nag mar karner madan karhi.

Rabir putra Jam raja Jam nam dhare

Bina aparadhe Jam karu danda nahi kore.

Chitragupta mahuri tar dibaratra lekhe

Jar jeman kapaler likhan bidhata likheche.

Bhalo lok hale dekhun krishnadute jai

Mandalok hole sadya jamdut jai.

Keu dhare chuler musthi keu dhare pai

Papilok hole sighra jamalaye pathay.

Apanar pati tajya kore je nari parapati seba kare

Tar mato papi dekhun naiko sansare

Khejur gache chare narir jamdanda kare.

Bhalo jal thakte je jan manda jal dei

Mrityu kale narakunder jal take jamdute dei

Satya Dwapar Treta Kali char juge parila

Kalir raja stritike gharhe laye, bura mar mathai

Chal daler topla diye gangasthan chalilen.

Mrityukale lohar dhenki pete chira kuta khai.

Mithya katha mithya prabanchana mithya sakshi den

Guru gobinda nam jini na len

Tapta Sanrasi kare tar jiuha tene len.

Hiraman name besya chilo gahan paper papi

Annadan bastradan sadhu sange harinam kare

Pran parityag karile krishnadute Pusparathe baikunthae laye gelo.

Ja khaoyaben ja bilaben oi na rahibe sar

Krishna name dan karlle boikunthe dhara roy.

Bara Ghar Bara duyar bara kara as

Sakal drabya pare roibe Gangatire basa.

(In this song of Patachitra of Krishna Lila the God Krishna described as the supreme power of the world like Vaisnava Myth. But as a writer or performer patua artist are not so powerful as Vaisnava poets. Because they have no proper education or training.)

\section{KRISHNA ABATAR}

Rajar Pape rajya nasta praja kasta pai

Ginnir pape girasta nasta gharer lakshmi ure jay.

Maharajer dese dekho jal nayeko holo

Rajar prajagan kasta paye palaite lagilo.

Narad muni kaiche sunen mahasay

Sanike badhile pare tabe jal hoi.

Rath ghora pira sarathi sajiye

Mahajar sanike badhite chalilen.

jata tata maren ban sanir upare

Kansha rajar dese harir nam jeba libe

Hate beri paye beri bakshasthale pasan chapa dibe.

Kotha chilen Basu-Daibakini harir nam je liache.

Swet machir rup dharan kore narayan dekhan swapan

Tomar garbhe tilek daogo thani.

Chay putra halare bap Kansha raja mereche kachire

Ek putra hoye kiba bhagya habe.

Ek mas dui mas mayer hoilo kanakani

Tririya pancham maser samay holo janajani.

Dash mash das din mayer subha purna ho'lo

Basumati daima hoye nije krishnake kole kore nilo

Aonyale jaonyale dichen basudeber kole

Basudeb lukaite challa nandalaye Nanda Ghoser ghare.

Kristake dekhe jamuna uthale uthilo

Bhagabati Srigal Murti hoye jamuna par holo.

Dash mash das din chilen mayer udare 
Amar garbhe chan karen thakur bhagya hok mor.

Ek kanya hoyeche raja bhiksh dao more

Kiba kanya kiba putra marla rajak-patharer upare.

Hate hate Bhagabati swarge ure gelo.

Amake je meli beta kansha durachar

Toke je maribe beta gokule ache ghar.

Rajar bhagni Putana stane bish mekhe gaman karilo

Sai sai bole jakhan sambandha karilo

Antarjamini thakur sab janilo.

"Koha" Koha" kare jakhan kende je uthilo

dekhun putanar kole dilo.

Ek chumuk, dui chumuk, tritiya chumuker belai putana badh holo

Putana mala bhaloi halo sabda gelo dure

Putana pore roilo choudda bhuban parbat saman jure.

Krishner janma sune deb debatagan bara anandito hoilo.

Sib nache Brambha nache ar nache Indra.

Gokule Gopal nache paiye gobinda.

$\mathrm{Ki}$ ananda holore bhai gokul nagare

Nander Ghare Nandochchb

Nander mathai dadhi dugdha chana makhan dhalolo.

Khol baje karatal baje mridanga baje hate

Baku murari baje sakhiganer mukhe.

Chari dhare Sakhigan madhye Shyamrai.

Dhale dhale paren dhekha ramanider gay.

Brindaboner madhye tarulata eriberi jay

Bhomra bhomri tai harigun gai.

Khela-rase chilen kanai subaleri sane

Haribe gopiganer bastra tai pare gelo mane

Bastra dao thakur poridhan kori

Sukno bastra pore bujhi nam rakhib kali.

Kali kali bolis na go suno goyalar jhi

Bidhata korechen kalo amar sadhya ki?

Bastra jadi na dio thakur jabo kansa rajar thai

Kangseri tape thakurer jati kul nai.

Bare bare dis na tora kangser bhagini putana.tulana

Abodh kale badhichilan Kansher bhagini Putana.

Gach hote nam thakur pere dao phul

Dal bhenge pa're marbe sunya hoye Gokul

Dal beri jakhan bastra pere dilo

douradouri kore sakhira takhan nagare chole gelo.

Sajo sajo bole barai nagare dile sara

Barai burir barta paye nagare dile sara.

Keu korle ras-bilyes keu sajalen dadhir pasara

Nanda gelo bathane Jasoda gelen jale.

Khali ghar paye dustu nani churi kare

Nandarani dekhte paye bandhen jugal kore.

Bendho na ma Nanda rani bandhan Jwalai? mari

Hateri murari beche diba nanir kari.

Sakhira bale amara je Mathura jabo bhar ke bayabe

Jagadiswar hari achen tini bhar bayaben.

Subha subanyar bhar dilen belalya pater sika

Krishner kandhe loye bhar chalilen radhika

Thakur ballen ami to bhar bayai nai jagateri sar

SriRadhikar premer janya kandhe boyai bhar.

Jale Krishna thale Krishna krishna mahimandale

Eka krishna nam dharen jagat sansare.

Bara ghar, ma, bara duyar, bara kara asa

Sakal drabbya pare roibe gangar tire basa

(This is another Patachitra of Krishna lila ,composed by another patua Artist)

KRISHNA LILA

Hari bine brindabane ar ki brajer sobha ache

Jale Krishna sthale Krishna krishna mahimandale.

Eka krishna nam dhare jagatsansare

Banka murari baje gopiganer mukhe.

Khol baje mridanga baje baje karatal

Tar madhye nritya kare Madangopal.

Dui dharete dui sakhigan madhye shyamarai

Dhale Dhale pare go sakhi ramanider gai

Keu nache keu bajay keu diche turi

Brindabaner majhe Nitai balen Hari Hari

Pahare bastra laye gopigan snane namila

Ake Ake Gopir bastra churi kore dalete bandhila.

Jhar nai jal nai bastra ke ba hare 
Nirlajya chora kala basan churi kare.

Bastra dao pranabandhu kapar dao he pari

Sukno bastra pore nam rakhbo kali

Kali Kali balo na shono gowalar jhi

Bidhata karechen kalo amar sadhya ki?

Kapar jadina dibi kanai jabo Kansha Rajar thai

Kanser tapete gopider jati kul nai.

Gach hote namo thakur pere dao phul

Dal bhenge pare marbe sunya hoye Gokul

Dal beriye thakur bastra pere dilo

Chotachuti gowalar kanya grihe chale gelo.

Sajo sajo bole Barai nagare dilen sara

Barai burir barta paye sajlo gowala para.

keu kare kesha binyas keu korechen turi

Hasta bhore bnar karlen subarner chiruni

Ardhek dure jaye thakur boslen Banamali

Mukhe bastra diye hanse Radha Chandrabali

Jetha dadhi na bikabe setha loye jabo

Munir Kheyale shyam nagare phirabo.

Daier lobo poune panch buri dudher lab kari

Ekti kara kam hole marba chongar bari.

Age jay Nandarani pechute barai

Bharkhani boye jay ei srinander Kanai.

Nagbati duti kanya upasthit hoilo

Kharra kharasi mayer hridayer kachuni.

Nikunja pargo dwarer prahari. Aa- Aa- Aa.

Ajagar churate ma basilen Bisahari.

Joy diye bandilam go ma joy bishahari

Asta nage bhar kare padmer kumari

Padma phule janma ma tor padma nam kamala

Padma nam Kamla ma tor Padma nam Kamala.

Aj Sridam Sudam Damodar subal gosthete sajilo

Singuli dhabali gabhir pal chere dilo

Palilo dekho phal gai baner pala jala khai

Chura dile dhara dile pachuni dile hate

Godhenu charate jai dada Balaramer sathe.

Eikhane ei krishna dakho ei nagariya thana.

Aj krishner gale dile banamala.

Abir putra Jamraja Jam nam dhare

Bina aparadhe Jam kauri danda nai kare.

Ekjan balte tara dui jane jai.

Keo dhare chuler musthi keo dhare gai.

Papi lok hole lohar dange bere go tar mastak phatai.

Bhalo jal thakte je jan manda jal dei

Mrityu kale narakkunde mukhe tar sei jal dei.

Dhenki pete je jan lokke dhan bhante na de

Mrityukale jamer dute dhekite tar mathate pahar dai,

Mastake tar harer chire kute khai. Apanar pati chere je jan parapati bhaje

Khejur gache chapi narir jam danda kare.

Jagannather puri jete jatrigan bara pai go dukh

Dekhile punna hoi go dekhile chand mukh.

Harir khai torhani ma go kuberer khay jhanta,

Khat palanka pare rabe nadir tire basa.

Hai re hari bine brindabane ar ki brajer sobha ache,

Hari bine brindabane ar ki brajer sobha ache.

.( This is another song of patachitra of KrishnaLila,Composed by another patua artist)

\section{Conclusion:}

We have known that the God Krishna is very popular among Indian devotees and also popular to the foreigners. From many thousands of years the name of the God Krishna has existed in the blood of devotees around the whole world. Everyday we pray, we worship to the God Krishna for our goodness. In the passage of time, the story of Krishna has transformed in various forms in many mediums and in many myths. In Patachitra art we have seen the story and life of Shree Krishna has transformed in many folk forms. We have to remember that Patachitra is an important folk medium of art and culture of India. From the folk songs of patachitra of Krishna Lila we can easily understand that the God Krishna is everywhere in world. Beside this we have to remember that the holy book 'Bhagabada geeta' has known as worldly myth of Krishna (specially known as the immortal words of the God shree Krishna). So the life and works of the God shree Krishna has considered as mythology. We know the word 'mythology' can refer either to the collected myths of a group of peopletheir body of stories which they tell to explain nature, history, and customs — or to the study of such myths. As a collection of such stories, mythology is an important feature of every culture. We know that the term 'Myth'means 'A traditional story concerning the early history of a people or explaining a natural or social phenomenon and typically involving supernatural beings or events'(See, Concise Oxford English Dictionary,2011). To remember this we have tried to discuss the cultural importance of Patachira of KrishnaLila. In this occasion it has also to be remembered that all artistic creatures including art 
and literature, which had formed on the subject of the life and work of Shree Krishna(including Mahabharata), has known as important mythological element of India and is signifying strong cultural phenomenon of our nation.

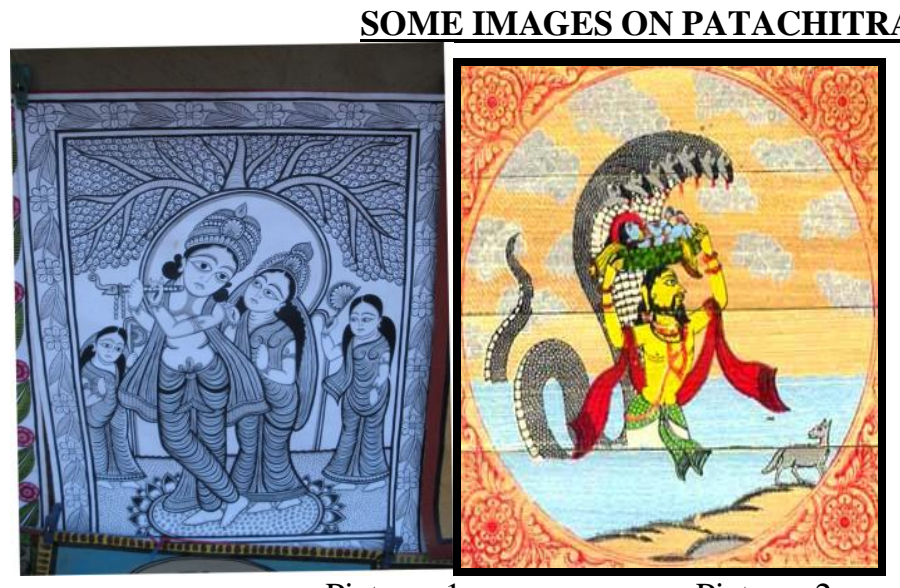

Picture -1
Picture -2

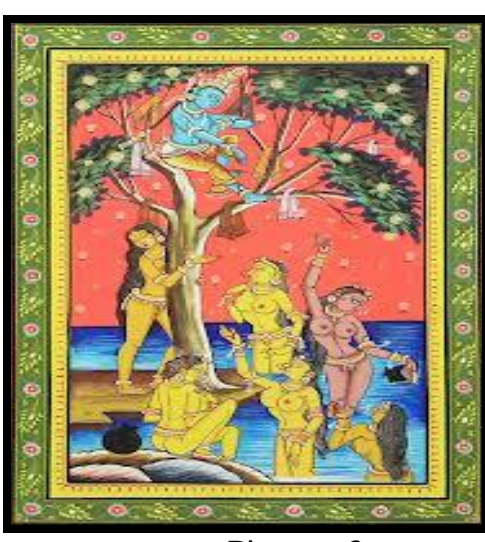

Picture -3

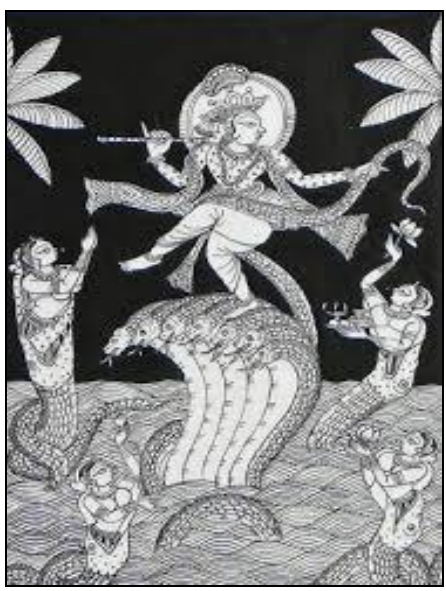

Picture -4

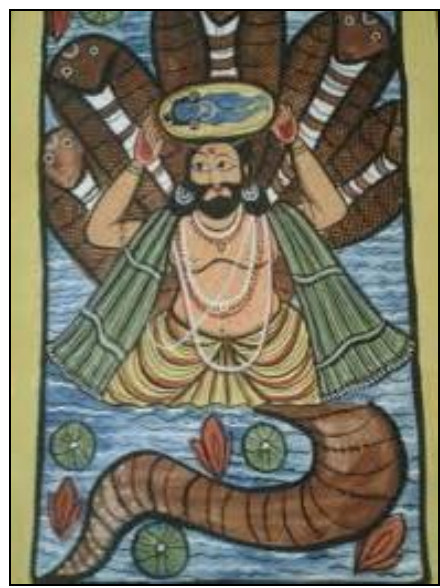

Picture -5

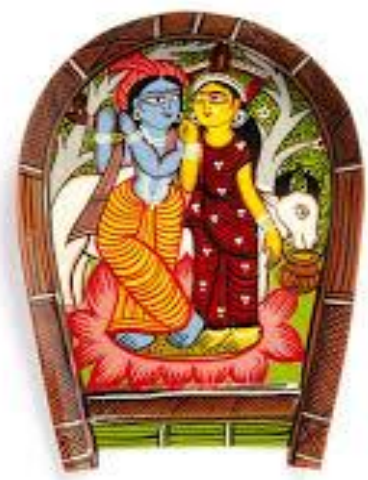

Picture -6

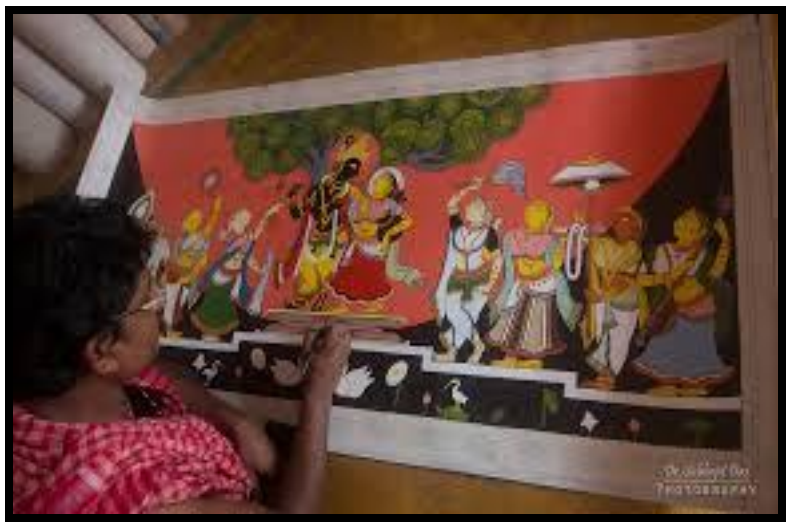

Picture -7

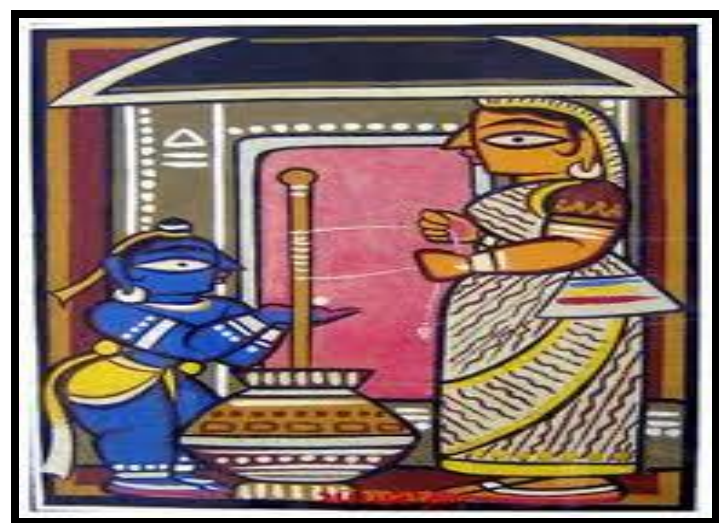

Picture -8 


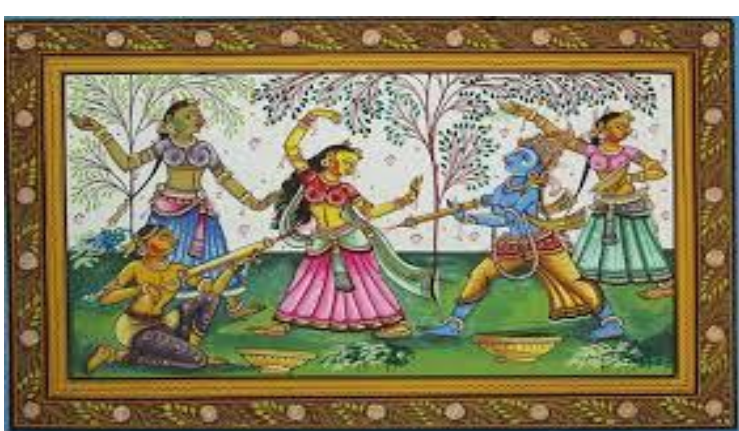

Picture -9

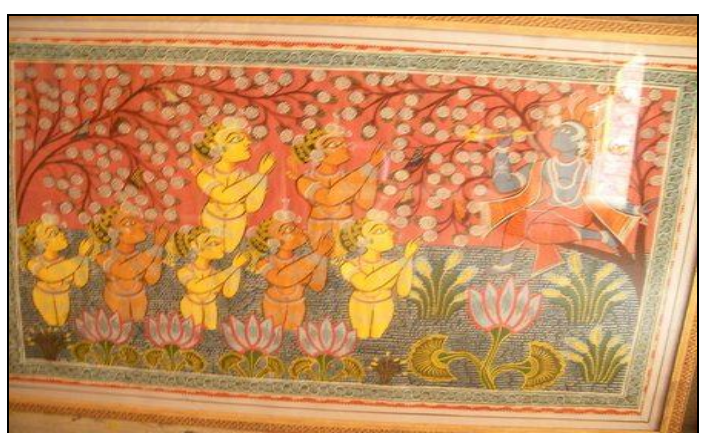

Picture- 10

\section{Description of the pictures}

Picture -1- This picture of Patachitra is depicting Brindabana Lila.(Brindabana is famous place for the devotee of Krishna. We, all Indian believed that The God Krishna truly appeared in Brindabana) .

Picture -2- This picture of Patachitra is depicting the birth lila Of Shree Krishna. (like as the picture-5)

Picture -3- This picture of Patachitra is depicting Bastraharan Lila. We have to remember that it is the symbolic concept of Krishna Philosophy. The 'bastra' or cloths signifying here as 'Maya', has considered as greed.

Picture -4-This picture of Patachitra is depicting KaliadamanaLila.The God Krishna was defeating the poisonous snake Kaliya Nag in a war and then he was dancing on the head of the poisonous snake Kaliya Nag.

Picture -5- This picture of Patachitra is depicting Shaisab lila of Krishna.His father Basudeva on the way to find the safe place (home of the King Nanda) for his child Krishna. In this picture he was crossing the river Jamuna.

Picture-6- This picture of Patachitra is depicting Radha and Krishna in attitude of Love appeared upon a Lotus.

Picture -7- This picture is depicting a devotional patua artist, who has been creating a patachitra of Krishna Lila Picture -8- This picture of Patachitra is depicting Shaishab(Child) Lila of the God Krishna and mother Joshoda. Picture -9- This picture of Patachitra is depicting Dol-Lila utsab(Festival of Color) of Krishna at Brindabana.

Picture -10- This picture of Patachitra is depicting Brindabana Lila of Krishna with Radha and other Gopinis.

\section{Bibliography}

[1]. Asit Kumar Bandopadhyaya, Bangala Sahityer Itihas, Modern Book, Kolkata,1999

[2]. Indrajit Sarkar, Literary Theory, Books Way, Kolkata, 2012.

[3]. M. H. Abrams, A Glossary of Literary Terms, Prism Books, Bangalore, 1993

[4]. J.A. Cuddon, Literary Terms and Literary Theory, Penguin Books, London, 1998

[5]. Mahajarul Islam, Folklore Charchai Ruptatwik Bishleshan Padhyati, Lok Loukik Prakashani, Kolkata, 1982

[6]. Kshetra Gupta, Sanjoger Sandhame Lok Sanskriti, Pustak Bipani, Kolkata, 1992

[7]. Dibyayoti Majumder, Lokakathar Aitijhya, Pustak Bipani, Kolkata, 1986

[8]. Ashutosh Bhattacharya, Banglar Lokshruti, Deys Publishing, Kolkata, 1993

[9]. Manas Majumder, Lok Aitijher Darpane, Deys Publishing, Kolkata, 1993

[10]. Barun Kumar Chakraborti, Bangeeo Lok Sanskriti Kosh, Aparna Book Distributors, Kolkata. 2005

[11]. Animeshkanti Pal, Lok-Sanskriti, Pragynabikash, Kolkata, 2006

[12]. Barun Kumar Chakraborti, Lok Biswas O’ Lok-Sanskar, Pustak Bipani, Kolkata, 1995 